\title{
GIS-Based snow avalanche hazard mapping: Bayburt-Aşağı Dere catchment case
}

\section{Authors Info}

A. Aydin and R. Eker*

'Department of Forest Engineering, Faculty of Forestry, Duzce, 81620, Turkey

*Corresponding Author Email : remzieker@duzce.edu.tr

Key words

Hazard map,

Potential release zone,

Snow avalanche,

2D simulation

\section{Publication Info}

Paper received : 30.07 .2016

Revised received : 20.06 .2017

Accepted : 27.06.2017

\section{Abstract}

Aim: The main objective of the study was to carry out GIS based large scale mapping of snow avalanche hazard. Aşağı Dere catchment in Bayburt city in Turkey were selected as study area because many settlements in this area have suffered and adversely affected from avalanches. For example, avalanche event of $18^{\text {th }}$ January 1993 caused death of 59 people, injury to 21 people.

Methodology: Snow avalanche hazard mapping involved: determining potential snow avalanche release zones; calculation of avalanche extents by $2 \mathrm{D}$ snow avalanche simulation software and generating hazard maps by combining previous two steps. Four villages that suffered snow avalanches were also evaluated in terms of avalanche hazard.

Results: In total, 3502 release zones, that cover $1992.2 \mathrm{ha}$ (10.3\%) of study area were determined. 7269.1 ha that is $37.5 \%$ of total area.

Interpretation: Hazardous areas in terms of avalanches need to be determined for definition of avalanche hazard situation and for land use planning. To create hazard maps in terms of snow avalanches, the most feasible approach is the use of Geographical Information Systems, combining topographical parameters.

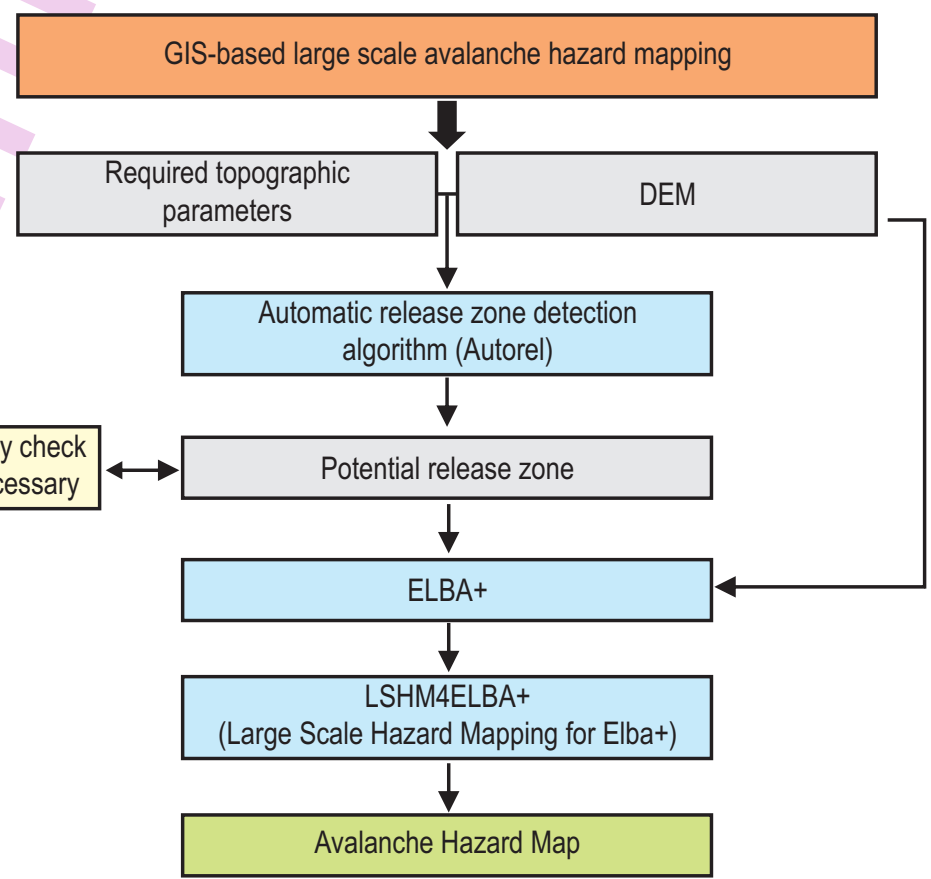




\section{Introduction}

Avalanches are a serious issue in Turkey, management of snow avalanches has not yet attracted the necessary attention. When avalanches occur, there is at present no one responsible for recording and documenting the events, drawing outlines or making required measurements and analyses. Therefore, only a few recorded events are available, and today, an updated avalanche database in Turkey is a demanding task (Aydın et al., 2014).

Snow avalanches are among the most important disturbance that threaten people, facilities, and traffic routes, and that affect mountain ecosystems (Bebi et al., 2009). Snow avalanches, which contain rock, soil, broken trees or ice in addition to snow, are very short, local, dynamic events in mountainous regions. Even though snow avalanches are considered as mountain slope hazards, extreme dangerous avalanches can occur anywhere combined with deep snow and steep terrain. Regardless of proximity or remoteness to the mountains, avalanche risks/hazards must be considered while planning land use. Economic development has led to increase and uncontrolled use of land, and hence land use planning has become necessary to prevent further extension of settlements into areas endangered by avalanches (Sauermoser, 2006).

The simplest strategy is to avoid the presence of any human being or constructions in an endangered area. Management of mountain hazards and risks due to snow avalanches requires careful analysis and assessment. Analysis of earlier events is considered as starting point, and hence it is absolutely necessary to collect data for actual events when they occur (Hübl et al., 2002). Prediction of avalanches is not an easy task especially when reports on observation of past events are absent or limited. A sustainable event management includes all information available for past events with or without respective damages as well as of current processes (Hübl et al., 2002). These include isolated observations (especially events causing accidents or resulting in heavy damages) made by individual experts under field conditions (Bühler et al., 2009). Though one has observations, forecasting avalanches is difficult task due to high spatial and temporal variability of snow pack properties and the complex interaction of the layers from growth of the snow pack to the releasing of an avalanche (Schweizer et al., 2008; Bühler et al., 2009).

The aim of hazard mapping is to present the spatial variation of hazard on geographical maps. Avalanche mapping is the drawing of avalanche paths or the delineation of avalanche hazard areas. The oldest avalanche maps are avalanche cadastres (Gruber and Haefner, 1995). These maps do not give any evidence about potential avalanche risks caused by extreme or changing environmental conditions. Mapping of avalanche hazards is mainly done to prevent catastrophic damage to people, settlements and transportation facilities (Gruber and Haefner, 1995). Because avalanche hazard maps provide information about the size, frequency and areal extent of danger zone of potential avalanches, they become indispensable tools to study the areas that are prone to avalanche dangers and use them in evaluating avalanche risks (Brugnot, 1999). Avalanche mapping studies date back as the late $19^{\text {th }}$ century in European Alps (Frutiger, 1980). These studies were first made in Switzerland and then in other countries, such as France, Austria, Italy, Germany, Japan, Norway, Spain, Slovenia, USA and Canada by using similar methodology (Oller et al., 2013; RudolfMiklau et al., 2014). Avalanche hazard maps in Switzerland are compiled by combining an analysis of past events and avalanche calculations (Gruber, 2001). Hazard zoning was started in Austria around 1970 by the Federal Forest technical Service in Torrent and Avalanche Control (Sauermoser, 2006). In Norway, avalanche hazard maps have been used since 1979 (RudolfMiklau et al., 2015). In Turkey, the office of "Mountainous Areas Management (MAM)", organized under the Turkish Forest Service, is responsible for the hazard and risk mapping of natural hazards but no guidelines or regulations exist to define the process of hazard and risk mapping; therefore, there are no restrictions on land use (Aydın et al., 2014). Consequently, buildings, tourism facilities and traffic infrastructures are still being constructed in high-risk avalanche zones in Turkey. Recently, AFAD (Disaster \& Emergency Management Authority) department published a guideline to record and analyse avalanches. However, guideline contains considerable vagueness and uncertainties in record and analysing process.

Avalanche maps are prepared from topographic maps by plotting field observation based on long-term experience and records (Salm et al., 1990). Past avalanche events give an idea of the size and type of avalanche that may occur in the future (Maggioni and Gruber, 2003). Depending on the map content and methods used in data collection and data processing avalanche hazard maps can be classified as I)hazard registration maps, II) geomorphic hazard maps, and III) hazard zonation maps (Hestnes and Lied, 1980). First type maps show past slides and avalanches, compiled from literature, documents, interviews, and fieldwork. Second type maps show past slides, avalanches and areas exposed to natural hazards identified by geomorphological investigations. Third type maps show potential risk areas, identified on basis of geomorphological investigations and past events. In order to predict potential run-out zones mathematicalstatistical methods (Hestnes and Lied, 1980), and computer based simulation models (Christen et al., 2010; Volk and Kleemary, 1999) are applied. The most systematic classification has been made by Rudolf-Miklau et al. (2014) as: I) Hazard (indication) maps, II) Process (Intensity) maps, III) Hazard zone plans, and IV) Risk maps. Hazard-indication maps depict areas where can expect avalanche danger and are in general drawn for large territorial units with less accuracy. Scales used for this 
purpose vary from $1 / 10000$ to $1 / 50000$. Hazard zone maps give further information about frequency and intensity of avalanches plotted based on a land register. High value risk maps for avalanche is available only for individual studies. In some countries there are maps containing simplified approaches for avalanche risk, they have not been standard for avalanche protection planning in Europe (Rudolf-Miklau et al., 2014).

In the present study, large-scale snow avalanche hazard map was generated based on topographical parameters. For this aim, potential avalanche release zones were determined first and then avalanche flow extents were determined by using $2 \mathrm{D}$ snow avalanche simulation model ELBA+. After snow avalanche hazard-indication map was generated, it was overlapped with locations of known avalanche events for validation.

\section{Materials and Methods}

Study area : Aşağı Dere catchment located in Bayburt city (NE of Turkey) was selected as study area. The coordinates of the area are $600616 \mathrm{~N}-4486680 \mathrm{E}$ and $623320 \mathrm{~N}-4470141 \mathrm{E}$ in UTM European Datum 1950 Zone 37. Catchment area covers 193.9 $\mathrm{km}^{2}$ (Fig. 1). There are 15 villages in the catchment (Table 1). Total population of the villages is 3199 (TUIK, 2014). Altitude of the catchment varies between $1483-3326 \mathrm{~m}$ (a.s.l). According to the elevation map (Fig. 2), 99.5\% of total area is higher than $1500 \mathrm{~m}$. According to the slope map (Fig. 2), 12.3\% of total area is located
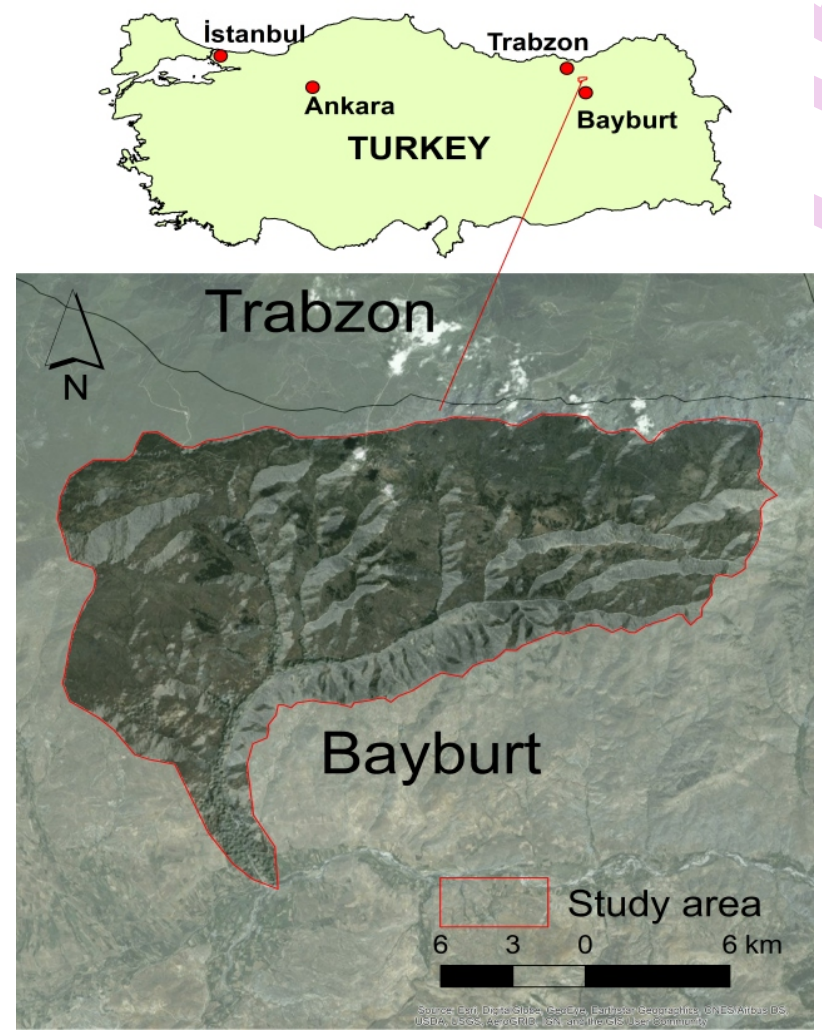

Fig. 1 : Location map of the study area
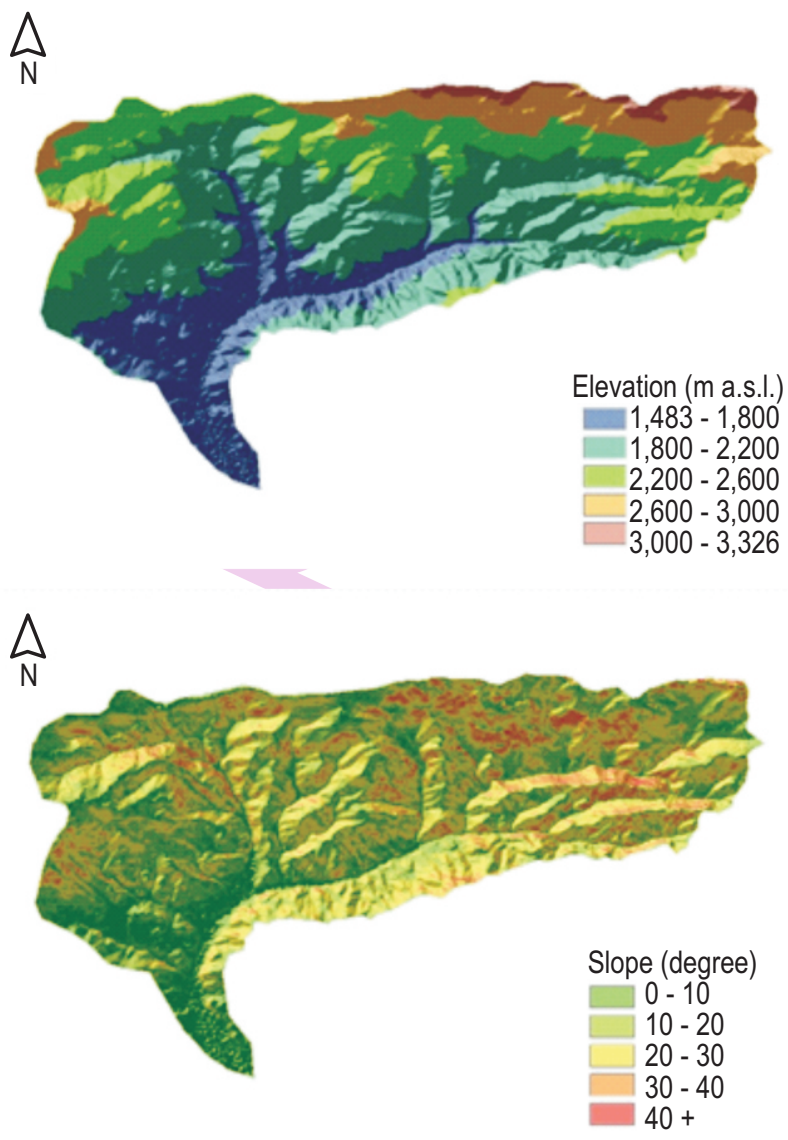

Fig. 2 : Elevation map (upper) and slope map (bottom) of the study area

Table 1: Villages in the catchment and total population (TUIK, 2014)

\begin{tabular}{ll}
\hline Village & Total population \\
\hline Akbulut & 264 \\
Ardicgoze & 56 \\
Armutlu & 123 \\
Cigdemlik & 228 \\
Erikdibi & 234 \\
Göloba & 80 \\
Karlica & 71 \\
Kilickaya & 61 \\
Kocbayir & 136 \\
Konursu & 1312 \\
Kozluk & 154 \\
Pelitli & 37 \\
Sarimese & 160 \\
Sirataslar & 152 \\
Üzengili & 131 \\
Total & 3199 \\
\hline
\end{tabular}

in slope that varies between $28^{\circ}$ and $55^{\circ}$. The climate has continental characteristics because the high mountains located at north run parallel to Black Sea coastal line causing decrease in 
effects of maritime climate. Winters are long, very cold and hard, summers are short, warm and arid. In winter, precipitation is in general snow fall. In Bayburt city, annual rainfall is $463.7 \mathrm{~mm}$ (Kordali and Zengin, 2007). Only $4 \%$ of total area in Bayburt city is covered with forests. The dominant vegetation is steppe, excluding small forests composed of pine, oak and juniper trees (Yazıcı, 1995).

Large scale snow avalanche hazard mapping : The work flow of the study was divided into three basic steps: 1) GIS-based determination of the potential release zones using topographic parameters, 2) two-dimensional numerical avalanche simulation and (3) formation of large scale hazard map. In the first step, methodology previously used for GIS-based determination of potential release zones by Aydın and Eker (2014) was used. For automatic detection of release zone, an algorithm, called "Autorel", developed by Bühler et al. (2013) was used. This script works under ArcGIS 10.1 software as toolbox. The main input of this algorithm is Digital Elevation Model (DEM). DEM used in the study was generated from digital topographical map with scale of $1 / 25000$. The pixel resampling size was chosen as 10 in meters. Other parameters of script are relevant topographic features (curvature, slope, ruggedness, and elevation) which are considered to have very important role in identifying whether one area is a potential release zone. For the study, curvature value, incorporated with ruggedness value and ruggedness threshold, was selected as 0.03 (means that more concave slopes without ridges will be selected as starting zone). Minimum and maximum slope values were selected as $28^{\circ}$ and $55^{\circ}$, respectively. Minimum and maximum elevations were selected as 1000 and 4000 in meters, respectively. Potential release zones identified may be checked manually and when necessary edited by the expert. For 2 dimensional numerical avalanche simulation, the same methodology was used as Volk et al. (2015). For this aim, ELBA+ (Energy Line Based Avalanche) software, based on the Voellmy model, was used. ELBA+ simulations require two parameters: the Coulomb friction $\mu$ and the velocity squared dependent turbulent friction $\xi$. In addition to these two parameters, release zones $\left(\mathrm{m}^{2}\right)$, release height $(\mathrm{m})$, snow density in the release zone $\left(\mathrm{kg} \mathrm{m}^{-3}\right)$ and DEM data are necessary inputs for simulations, with entrainment and resistance areas being optional. For the preparation of avalanche hazard map from ELBA+ results, an algorithm was developed by the authors. This algorithm, called LSHM4ELBA+ (Large Scale Hazard Mapping for ELBA+), was used to form hazard map in the study area. LSHM4ELBA+ is a script that works under the ArcGIS 10.1

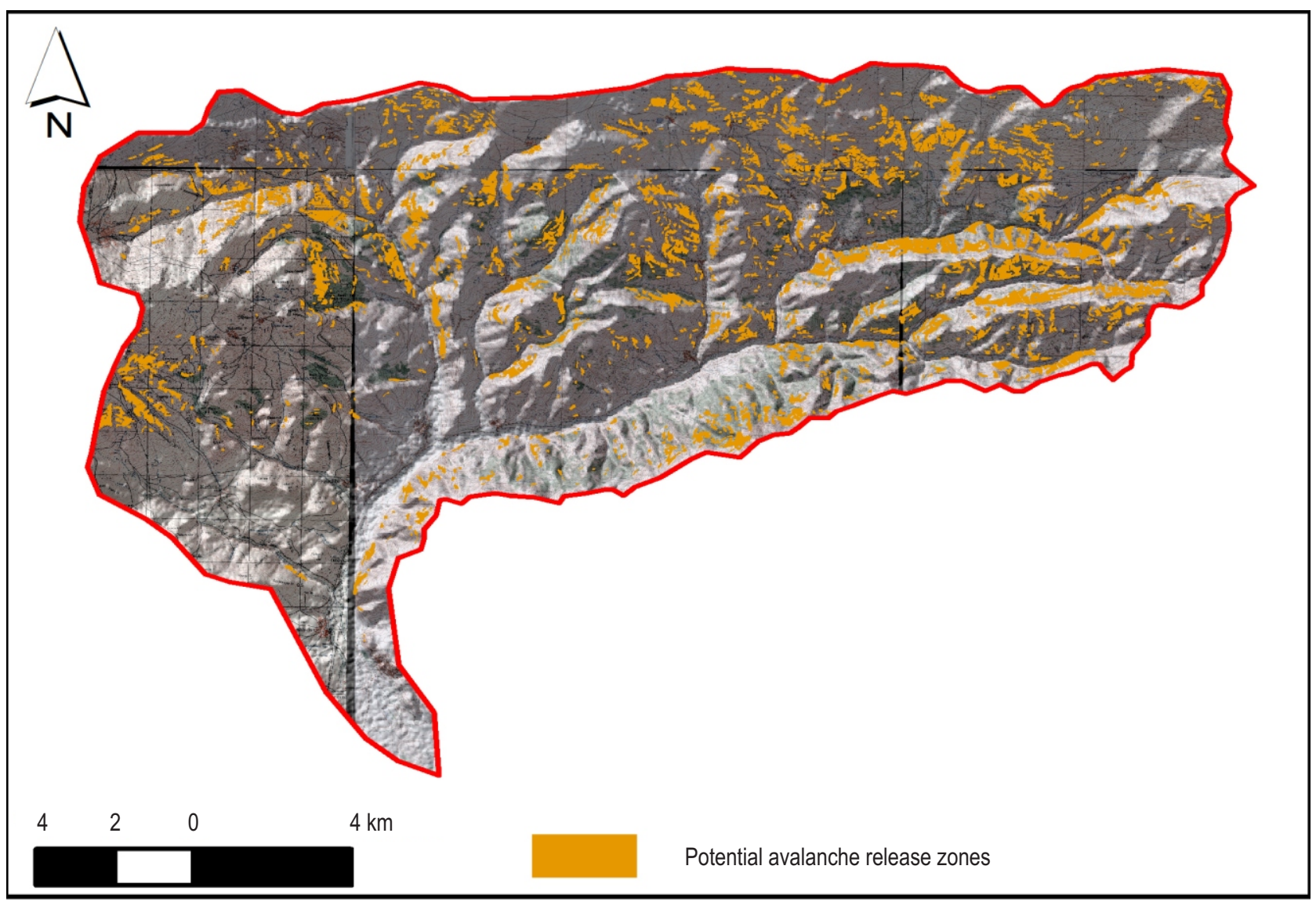

Fig. 3 : Potential release zones determined in the area 


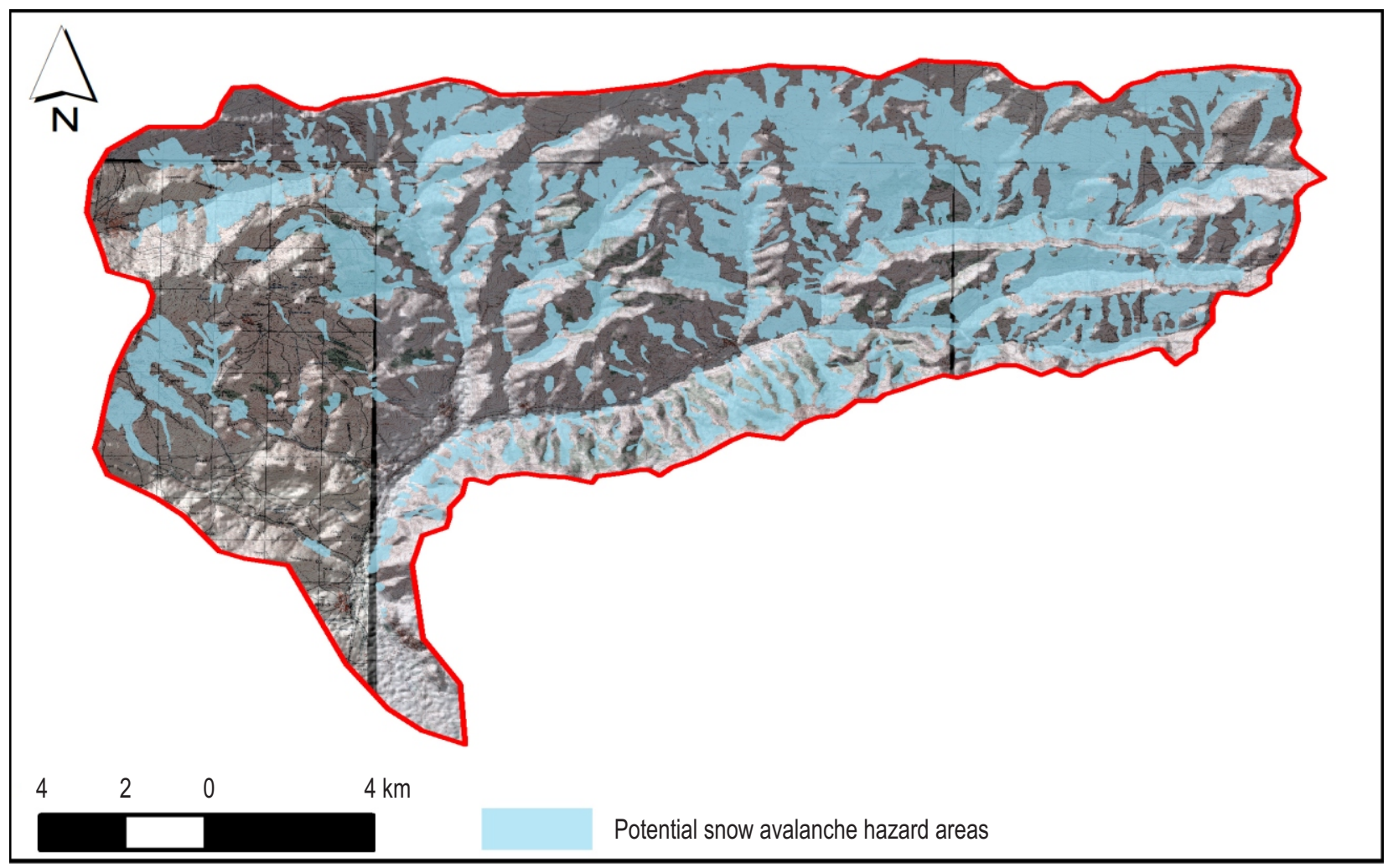

Fig. 4 : Avalanche hazard map

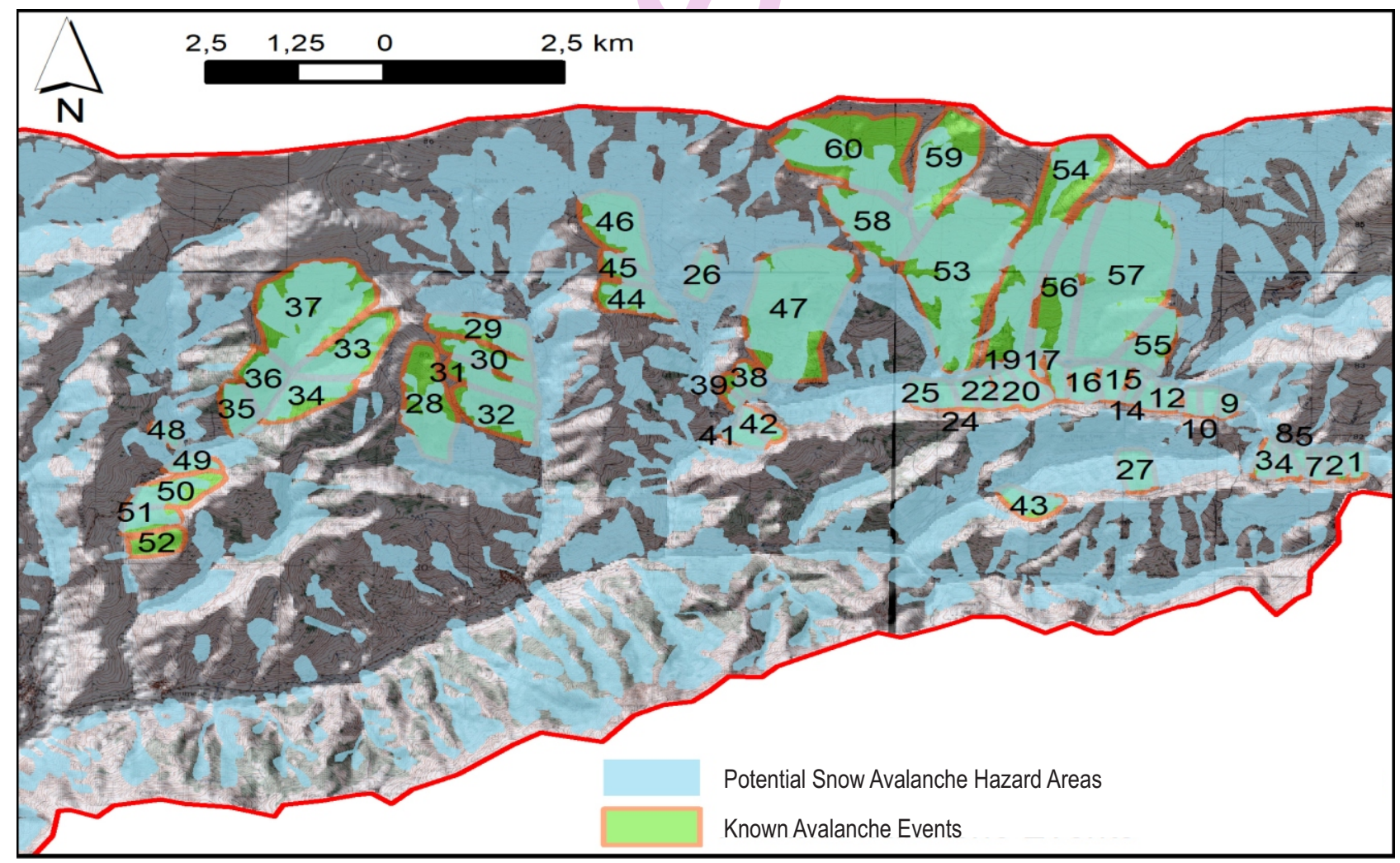

Fig. 5 : Avalanche hazard map overlapped with known avalanches 
software like Autorel. This algorithm requires only completed ELBA+ simulations that are geodatabase files with extension of ".mdb". The avalanche hazard map prepared was overlapped with the locations of known avalanche events for comparison and validation. For this aim, the locations of past avalanches in the area were plotted over $1 / 25000$ topographical map in digital format and a database was formed to give each event an ID number. Information about avalanches in the area was obtained from interviews made with local people during the field works made in 2013. It should be noted that this information provides us only locations of past avalanches, nothing more.

\section{Results and Discussion}

For preparation of large scale snow avalanche hazard map in Aşağı Dere catchment in Bayburt city located in Eastern Black Sea Region, potential release zones were first determined using an algorithm developed for automatic detection of potential release zones in the area (Fig. 3). According to the outputs of this algorithm, a total of 3502 release zones was determined in the area. Areal size of the release zones varies between 0.0142 ha

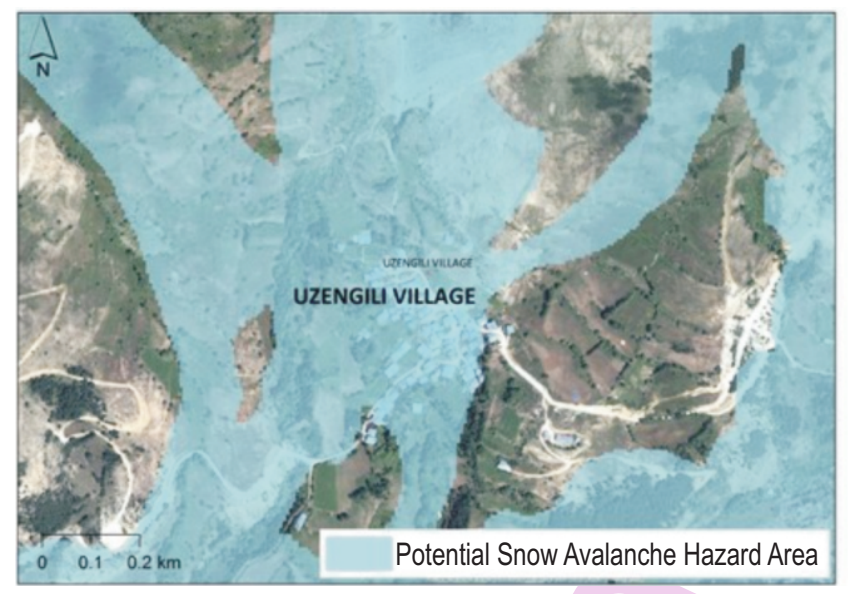

(a)

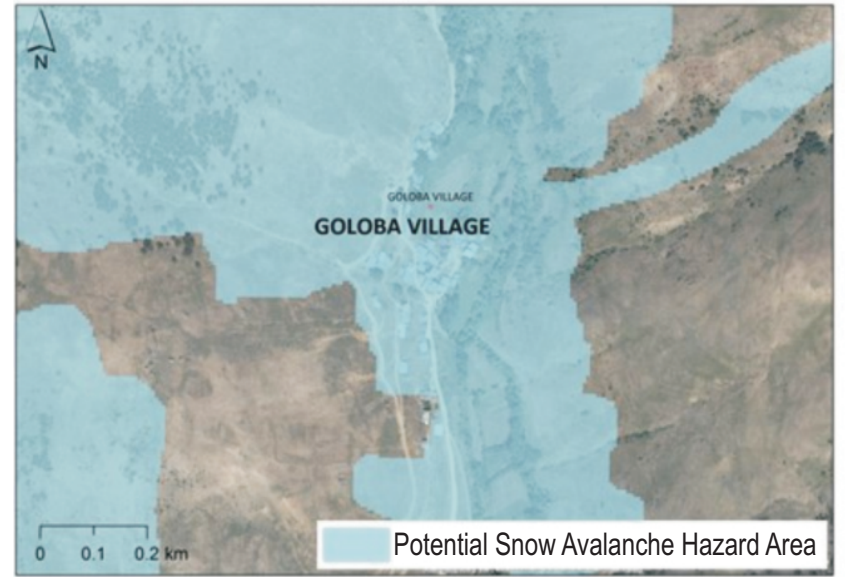

(c) and 6.23 ha. Potential release zones cover 1992.2 ha corresponding to $10.3 \%$ of total area.

After potential release zones were determined, 2D avalanche simulations were made using ELBA+ 2D snow avalanche dynamic software to get flow extents of avalanches. Then avalanche hazard map generated using LSHM4ELBA+ algorithm from the results of ELBA+ simulations. The final avalanche hazard map, shown in Fig. 4, shows that extents of avalanche hazard cover 7269 . 1 ha. This means that $37.5 \%$ of total area faces avalanche hazard. When snow avalanche map is overlapped with known avalanche events in the area, it is observed that generated hazard map is quite compatible with locations of known avalanche events. This overlapping method provides valuable information validating our snow avalanche hazard map. The overlapped map is given in Fig. 5.

In Aşağı Dere catchment, many of settlement area such as village and upland is located and 15 of this settlement area is village. In the villages, generally there are people who live during all seasons whereas in the uplands, people lives only for summer

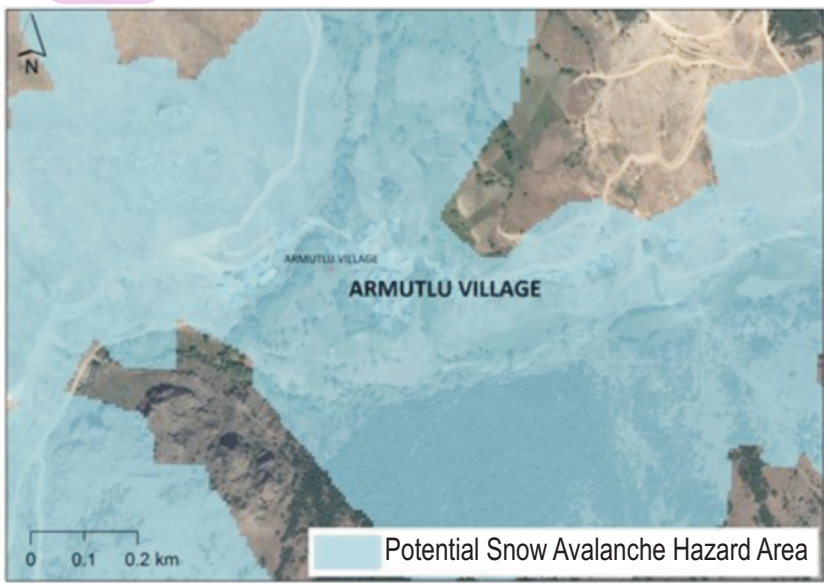

(b)

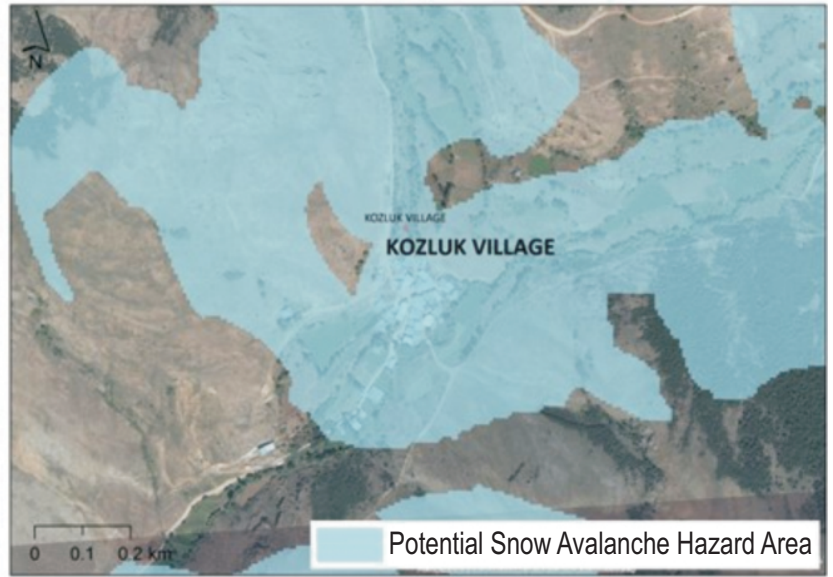

(d)

Fig. 6 : Avalanche hazard situations in the villages of (a) Üzengili (b) Armutlu (c) Göloba and (d) Kozluk 
seasons. Most of the uplands in the area is exposed the avalanche hazard. When villages are evaluated, it seems that snow avalanches in the area are crucial problems. Hence some villages evaluated in terms of avalanche hazard. One of those villages is Üzengili village that is one of the most suffered by the avalanches (Figure 6). Üzengili village is entirely located in the avalanche hazard zones. Known most killing avalanche event formed in $18^{\text {th }}$ January 1993 causing death of 59 people and injury of 21. In addition, avalanche buried 85 houses, 72 of which were completely destroyed or transported to the far end of the run-out zone (Aydın et al., 2014). Armutlu village, Göloba village and Kozluk village are also shown in Fig. 6. Because it is known from interviews made with villagers that avalanche events cause crucial problems in these villages.

Avalanches are a serious problem in Turkey. However, there is no agency responsible for recording and documenting the events, drawing outlines or making necessary measurements and analysis. Hence, there is no up-to-date avalanche database, except only a few recorded events, which caused deaths, injuries and/or economic damage. Because of mentioned reasons, avalanche hazard maps that provide information about the size and areal extent of potential and/or past avalanche episodes are not available. Hazardous areas in terms of avalanches need to be determined for definition of avalanche hazard situation and for land use planning. To create hazard maps in terms of snow avalanches, the most feasible approach is the use of Geographical Information Systems (GIS), combining topographical parameters.

\section{References}

Aydın, A., Y. Bühler, M. Christen and İ. Gürer: Avalanche situation in Turkey and back-calculation of selected events. Nat. Haz. Earth Syst. Sci., 14, 1145-1154(2014).

Aydın, A. and R. Eker: GIS-based determination of potential snow avalanche release zones using topographical parameters (Original in Turkish). II. Ulusal Akdeniz Orman ve Çevre Sempozyumu, 22-24 Ekim 2014, pp. 426-435 (2014).

Bebi, P., D. Kulakowski and C. Rixen: Snow avalanche disturbances in forest ecosystems. State of research and implications for management. For. Ecol. Manag., 257, 1883-1892 (2009).

Brugnot, G.: SAME-Avalanche mapping, model validation and warning systems, Summary Report, European Commision, European Environment and Climate Programme, p. 67 (1999).

Bühler, Y., A. Hüni, M. Christen, R. Meister and T. Kellenberger: Automated detection and mapping of ava-lanche deposits using airborne optical remote sensing data. Cold Regi. Sci. Technol., 57, 99-106 (2009).

Bühler, Y.S., Kumar, J. Veitinger, M. Christen, A. Stoffel and Snehmani: Automated identification of potential snow avalanche release areas based on digital elevation models. Nat. Hazards Earth Syst.
Sci., 13, 1321-1335 (2013).

Christen, M., J. Kowalski and P. Bartelt: RAMMS: Numerical simulation of dense snow avalanches in three-dimensional terrain. Cold Reg. Sci. Technol., 63, 1-14 (2010).

Frutiger, H.: Swiss avalanche hazard maps. J. Glaciol., 26, 518-519 (1980).

Gruber, U.: Using GIS for avalanche hazard mapping in Switzerland: Proceedings of the 2001 ESRI International User Conference, San Diego, CA. http://gis.esri.com/library/userconf/proc01/ professional/ papers/pap964/p964.htm (2001).

Gruber, U. and H. Haefner: Avalanche hazard mapping with satellite data and a digital elevation model. Applied Geography, 15, 99-113 (1995).

Hübl, J., H. Kienholz and A. Loipersberger: DOMODIS - Documentation of Mountain Disasters (State of Discussion in the European Mountain Areas), Internationale Forschungsgesellschaft INTERPRAEVENT, Schriftenreihe 1, Handbuch 1, Klagenfurt, p. 36 (2002).

Hestnes, E. and K. Lied: Natural hazard maps for land-use planning in Norway. J.Glaciol., 26, 331-343 (1980).

Kordali, Ş. and H. Zengin: Determination of distribution, density and sociability of weed species in wheat fields in Bayburt province (Original in Turkish). Atatürk Üniv. Ziraat Fak. Derg., 38, 9-23 (2007).

Maggioni, M. and U. Gruber: The influence of topographic parameters on avalanche release dimension and frequency. Cold Regions Sci. Technol., 37, 407-419 (2003).

Oller, P., M. Janeras, O. Costa, C. García-Sellés, E. Muntán, G. Martí and P. Martínez: Avalanche hazard mapping plan for the Catalan Pyrenees. International Snow Science Workshop Grenoble Chamonix Mont-Blanc-2013, pp. 604-610 (2013).

Rudolf-Miklau, F., S. Sauermoser and A. Mears: Technical Avalanche Protection Handbook. John Wiley \& Sons, p. 420 (2014).

Salm, B., A. Burkard and H. Gubler: Berechnung von Fliesslawinen: eine Anleitung für Praktiker mit Beispielen [Avalanche calculations: A practical method with examples] (in German). Eidg. Inst. Schneeund Lawinenforsch. Mitt., 47, p. 41 (1990).

Sauermoser, S.: Avalanche hazard mapping-30 years experience in Austria. Proceedings of the 2006 International Snow Science Workshop, Telluride, Colorado, pp. 314-321 (2006).

Schweizer, J., K. Kronholm, J.B. Jamieson and K.W. Birkeland: Review of spatial variability of snowpack properties and its importance for avalanche formation. Cold Reg. Sci. Technol., 51, 253-272 (2008).

Schweizer, J., K. Kronholm, J.B. Jamieson and K.W. Birkeland: Review ofspatial variability of snowpack propertiesand its importance for avalanche formation. Cold Reg. Sci. Technol., 51,253-272 (2008).

TUIK(Turkish Statistical Institute): http://www.tuik.gov.tr/UstMenu.do? metod=temelist (accessed in 22-11-2015) (2014).

Volk, G. and K. Kleemayr: Lawinen simulationmodell ELBA. Wildbach und Lawinenverbau, 63, Jg. Heft 138(1999).

Volk, G., A. Aydın and R. Eker:Avalanche Control with Mitigation Measures: A Case study from Karaçam-Trabzon (Turkey). Eur. J. ForestEng., 1,61-68 (2015).

Yazıcı, H.: A study from the viewpoint of urban geography: Bayburt (Original in Turkish). Türk Coğrafya Dergisi, 30, 189-218 (1995). 